\title{
REVIEW ARTICLE OPEN Pepper mild mottle virus as a water quality indicator
}

\author{
Masaaki Kitajima ${ }^{1}$, Hannah P. Sassi $\mathbb{D}^{2}$ and Jason R. Torrey ${ }^{3}$
}

Pepper mild mottle virus (PMMoV) was recently found to be the most abundant RNA virus in human feces, and is a plant virus belonging to the genus Tobamovirus in the family Virgoviridae. When in human feces, it is of dietary origin from peppers and their processed products, and is excreted from a large proportion of healthy human populations, but rarely found in animal feces. Over the past decade, this virus has been increasingly attracting research attention as a potential viral indicator for human fecal pollution in aquatic environments and water treatment systems. Results presented in the literature reveal that PMMoV is globally distributed and present in various water sources in greater abundance than human pathogenic viruses, without substantial seasonal fluctuations. Several studies report that increased concentrations of PMMoV tend to be correlated with increased fecal contamination in general, along with more frequent detection of pathogenic enteric viruses. PMMoV also exhibits remarkable stability in water under various environmental conditions. Here, we review recent advancements in our understanding of the occurrence and persistence of PMMoV in natural and engineered water systems and discuss its advantages and limitations as a viral indicator for improved microbial water quality management.

npj Clean Water (2018)1:19; doi:10.1038/s41545-018-0019-5

\section{INTRODUCTION}

Viral pathogens are a significant cause of waterborne illnesses, including gastrointestinal and respiratory conditions. Their detection and isolation in the environment has historically been difficult, due to the range of illnesses they may cause, method limitations, and their low concentration in water. ${ }^{1-4}$ Waterborne illnesses from viral pathogens has been reported for all water types; a majority of recreational water-associated outbreaks have been linked to viral pathogens, as well. ${ }^{3}$ Microbial indicators of fecal contamination have been implemented in water quality monitoring for a number of years throughout the world. ${ }^{5}$ Despite the evidence of viral pathogens in water, current recreation and drinking water standards in most countries rely heavily on fecal indicator bacteria (FIB), such as Escherichia coli, coliforms, and enterococci. ${ }^{6,7}$ Multiple issues are associated with using FIB for assessment of water quality. One is that there is little or no correlation between enteric virus concentration and FIB concentration in water, mainly due to the differing effects of environmental conditions on the two types of organisms. ${ }^{8-10}$ In addition, FIB can be transmitted and identified in secondary reservoirs outside of the mammalian intestinal tract and are, therefore, not directly indicative of human fecal contamination. FIB are typically more sensitive to traditional wastewater treatment and chlorination than many enteric viral pathogens. ${ }^{1,2,5}$ With this in mind, many researchers have proposed alternative fecal indicator organisms, including pepper mild mottle virus (PMMoV). The relevance of PMMoV as a fecal indicator stems from the discovery by Zhang et al. that, despite being a plant pathogen, it was found to be the most abundant virus type in human fecal samples. ${ }^{11}$ This study not only identified PMMoV as highly abundant in the human gut virome, but would ultimately initiate the beginning of research surrounding PMMoV as a potential fecal pollution indicator in water, facilitating its study in fecal and water samples throughout the world.

This review aims to present the current research, to date, surrounding detection, prevalence, and monitoring of PMMoV in major urban and agricultural water ways, including wastewater and water reclamation systems, environmental waters, and drinking water treatment systems. The purpose of this review is to compile current knowledge to enable researchers and policymakers to properly determine the usefulness and applicability of PMMoV as an indicator for water quality assessment and related practices.

\section{BIOLOGY OF PMMOV}

PMMoV belongs to the genus Tobamovirus in the family Virgoviridae $^{12}$ and was first formally described in the literature in 1984 when it was isolated from peppers in Italy. ${ }^{13}$ Since its discovery, PMMoV has caused significant economic and crop losses around the world, including the United States, ${ }^{14}$ Japan, ${ }^{15}$ and China. ${ }^{16,17}$ The virus is characterized as non-enveloped with a positive-sense, single-stranded RNA genome of approximately $6.4 \mathrm{~kb}$, that was sequenced for the first time in $1991 .{ }^{18}$ The virion is notable for its rod-shaped structure ( $312 \mathrm{~nm}$ in length), similar to tobacco mosaic virus and other tobamoviruses, which encapsidates a single copy of the RNA genome. An isoelectric point (pl) of $\mathrm{pH}$ 3.2-3.8 has been reported for PMMoV, ${ }^{13,19}$ which is similar to that of other tobamoviruses ${ }^{13}$ but lower than most enteric viruses. ${ }^{20}$ Originally isolated from Sicilian-grown Capsicum annum, PMMoV has been found to infect a wide range of pepper varieties $^{13}$ and is currently considered one of the major pathogens

\footnotetext{
${ }^{1}$ Division of Environmental Engineering, Faculty of Engineering, Hokkaido University, North 13 West 8, Kita-ku, Sapporo, Hokkaido 060-8628, Japan; ${ }^{2}$ School of Life and

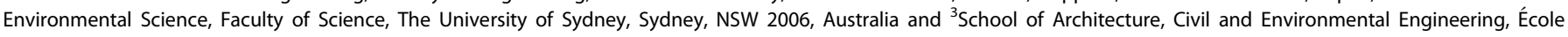
Polytechnique Fédérale de Lausanne, CH-1015 Lausanne, Switzerland

Correspondence: Masaaki Kitajima (mkitajima@eng.hokudai.ac.jp)

These authors contributed equally: Masaaki Kitajima, Hannah P. Sassi.
}

Received: 14 February 2018 Revised: 21 August 2018 Accepted: 21 August 2018

Published online: 15 October 2018 
in pepper species around the world. ${ }^{17,21}$ Its pathology in peppers includes symptoms such as small white mottles and systemic infection, although infected peppers may often remain asymptomatic or show only mild foliar damage, thus allowing the virus to replicate and spread without notice. ${ }^{17,21,22}$ Scientific attention to PMMoV was initially triggered because it was found to cause disease in a strain of pepper that was resistant to tobacco mosaic and tomato mosaic viruses. ${ }^{13}$ PMMoV is currently divided into five major pathotypes, distinguished by their ability to overcome tobamovirus-resistant genes in peppers $\left(L^{1}, L^{1 a}, L^{2}, L^{3}\right.$, and $\left.L^{4}\right) .^{22}$ On farms, PMMoV also remains viable for long periods of time in soils after infected crops have been removed or harvested. Composting and drying have been shown to only slightly reduce detection of PMMoV, but may impact the infectivity of the virus. ${ }^{23}$ Treatment of pepper seeds with $10 \%$ trisodium phosphate has been demonstrated to decrease infectivity, but does not result in total removal of the virus. ${ }^{17}$ The ability to survive extreme conditions and adapt to cause infection in resistance-bred peppers could explain PMMoV's abundance in pepper plants throughout the world. ${ }^{17,20,21}$

\section{METHODOLOGY FOR PMMOV DETECTION IN WATER}

PMMoV has been detected in water samples with the same methodologies commonly used for enteric RNA viruses, i.e., virus concentration followed by regular reverse transcriptionpolymerase chain reaction (RT-PCR) or RT-quantitative PCR (RT$q P(R)$. Various virus concentration methods, such as electronegative disk or cartridge filters, electropositive filters, and tangential flow ultrafiltration, have been utilized for concentrating PMMoV particles from various water sources, including drinking, surface, waste, and reclaimed waters. Thus far, limited studies have reported recovery efficiencies for PMMoV by these methods; Rosario et al. recovered between 63 and $77 \%$ of spiked PMMoV in treated wastewater using centrifugal ultrafiltration. ${ }^{24}$ Kato et al. ${ }^{25}$ reported typical recovery efficiencies of $>10 \%$ for
PMMoV when concentrating from drinking water matrices using electronegative filters with $\mathrm{MgCl}_{2}$, followed by acid rinse and elution with $\mathrm{NaOH} .{ }^{25}$

PCR primers that have been used for the detection of indigenous PMMoV in previous published studies are listed in Table 1. The qPCR assay developed by Zhang et al. has been widely used for the detection of PMMoV. ${ }^{11}$ Haramoto et al. pointed out that there was a mismatch with the reference sequence on the $3^{\prime}$ side of the forward primer and modified the forward primer by adding a thymine nucleotide so that the primer sequence perfectly matched target sequences of multiple PMMoV isolates. $^{26}$ The use of this modified primer (PMMV-FP1-rev) is recommended, although the original primer (PMMV-FP1) seems to work for fecal and environmental samples without a noticeable problem. Potential inhibition associated with PMMoV detection has typically been assessed with a process control virus used for human enteric viruses, such as murine norovirus (MNV); however, considerable morphological and surface charge differences (pl: 3.2-3.8 for $\mathrm{PMMoV}^{13,19}$ versus 4.8 for $\mathrm{MNV}^{27}$ ) exist between PMMoV (rod-shaped) and MNV (icosahedral), and therefore the relevance of using such viruses for assessing virus concentration, RNA extraction, and RT-qPCR efficiency is called into question. Kato et al. ${ }^{25}$ utilized cucumber green mottle mosaic virus (CGMMV), which is also a member of the tobamovirus group, as an internal control for determining extraction-RT-qPCR inhibition associated with PMMoV detection from concentrated drinking water samples. ${ }^{25}$ While the suitability of CGMMV as an internal control for PMMoV was not evaluated in detail within this study, it was assumed by the authors to be a more appropriate control given its phylogenetic and morphologic similarities to PMMoV. ${ }^{25}$ Further work is necessary to assess relevant controls for accurate estimation of potential inhibition associated with virus concentration, RNA extraction, and RT-qPCR processes for PMMoV detection and quantification in water samples.

\begin{tabular}{|c|c|c|c|c|c|}
\hline \multirow[t]{3}{*}{ qPCR } & Forward primer & PMMV-FP1 & GAGTGGTTTGACCTTAACGTTGA & $1878-1901$ & 11 \\
\hline & Reverse primer & PMMV-RP1 & TTGTCGGTTGCAATGCAAGT & $1945-1926$ & \multirow{2}{*}{26} \\
\hline & TaqMan probe ${ }^{\mathrm{b}}$ & PMMV-Probe1 & FAM-CCTACCGAAGCAAATG-BHQ1 & $1906-1921$ & \\
\hline \multirow[t]{9}{*}{ Conventional PCR } & Forward primer & $\mathrm{CP} / \mathrm{s}$ & ATGGCATACACAGTTACCAGT & $5685-5705$ & \multirow[t]{2}{*}{53} \\
\hline & Reverse primer & $\mathrm{CP} / \mathrm{a}$ & TTAAGGAGTTGTAGCCCACGTA & $6158-6137$ & \\
\hline & Forward primer & PMMoV forward & ATGGCTTACACAGTTTCCAGTG & $5685-5706$ & \multirow[t]{2}{*}{54} \\
\hline & Reverse primer & PMMoV reverse & TTAAGGAGTTGTAGCCCAGGTG & $6158-6137$ & \\
\hline & Forward primer & PMMV-forward & AACCTTTCCAGCACTGCG & $611-628$ & 11 \\
\hline & Forward primer & PMMoVcaps_Fwd & CGTTAGGYAATCAGTTTCAA & $5776-5795$ & \multirow[t]{2}{*}{29} \\
\hline & Reverse primer & PMMoVcaps_Rev2 & CGAACTAACTCATTCATGA & $6089-6070$ & \\
\hline & Forward primer & PM1602 & TGTTTCGGAAAAGGCTCTTG & $1602-1621$ & \multirow[t]{2}{*}{28} \\
\hline & Reverse primer & Ha-PMMV2 & ATTTGCTTCGGTAGGCCTCT & $1901-1920$ & \\
\hline
\end{tabular}




\section{POTENTIAL SOURCES OF PMMOV}

Fecal reservoirs

Identification of PMMoV in feces was first achieved through viral metagenomics and reported in 2006 by Zhang et al. ${ }^{11}$ They reported that the most abundant RNA virus in three fecal samples from healthy adults in the United States was PMMoV, comprising 75.7-99.4\% of all sequences identified in the fecal RNA viral community. ${ }^{11}$ Phylogenetic analysis of PMMoV strains identified in the fecal samples indicated that the PMMoV strains were very different even in two fecal samples collected from the same individual, which implies that the PMMoV circulation in human populations is dynamic. ${ }^{11}$ PMMoV was subsequently detected in feces by regular RT-PCR or RT-qPCR in six (67\%) of nine samples in the United States, ${ }^{11}$ six (67\%) of nine samples in Singapore, ${ }^{11} 19$ $(95 \%)$ of 20 samples in Germany, ${ }^{28}$ and in the specimens of one $(0.48 \%)$ of 208 hospitalized children and 22 (7.2\%) of 304 adult patients in France. ${ }^{29}$ Although the detection rate varies between studies, likely due to differences in detection methods or exposure to $\mathrm{PMMoV}{ }^{29}$ these studies have demonstrated that the presence of PMMoV in feces is geographically widespread (Fig. 1).

PMMoV concentrations in feces are high, ranging from $10^{5}$ to $10^{10}$ copies/g-feces (dry weight). ${ }^{11}$ PMMoV can be found with greater frequency in healthy human feces than pathogenic viruses. ${ }^{24}$ Strains isolated in human feces are genetically diverse with dynamic fecal populations within an individual, and notably remain viable and infectious to host plants. ${ }^{11}$ One previous study documented interactions of PMMoV with the human immune system and suggested that the virus may cause clinical symptoms in humans, such as fever, abdominal pains, and pruritus; however, these symptoms may have been confounded by spicy food rich in peppers or pepper-based products and the proposed pathogenic role is unclear. ${ }^{29}$ These results should be re-evaluated in future studies.

PMMoV has not been detected in fecal samples or intestinal homogenates of most animals, such as turkeys, horses, coyotes, raccoon, sheep, ducks, pigs, and dogs. ${ }^{24,28}$ Although fecal samples from cows, geese, seagulls, and chickens were sometimes positive for PMMoV, virus concentrations in these samples were much lower (3-4 logs) than those in human feces; the originating source of PMMoV in these animals is unclear. ${ }^{24,28}$ Future studies should further investigate the specificity of PMMoV and, if detected in animal samples, attempt to ascertain the potential sources (dietary or otherwise) to determine the potential of utilizing PMMoV for human fecal source tracking.

Plant and food sources

Not only has PMMoV been found to persist in farm environments, it has been shown to persist through multiple food processing protocols. Upon its original isolation, it was found to survive at $90^{\circ} \mathrm{C}$ for up to $10 \mathrm{~min}$ in plant sap. ${ }^{13}$ Zhang et al. found PMMoV in three processed pepper products from San Diego, including chili sauce and powdered chili, and four chili sauce samples from Singapore. ${ }^{11}$ A study performed in France also reported that PMMoV RNA sequences were identified in 12 (57\%) of 21 commercialized food products containing peppers, such as sauces and powders. ${ }^{29}$ This study revealed that Tabasco $^{\circledR}$ sauce contained the highest estimated PMMoV-RNA concentration of nearly $10^{7}$ copies $/ \mathrm{mL}$, and the presence of viral particles was confirmed by electron microscopy. In addition, it was demonstrated that PMMoV RNA-positive processed products contained viable PMMoV particles capable of infecting host plant. ${ }^{29}$ These findings collectively demonstrated that intact PMMoV particles can persist through standard food processing involving high thermal exposure and low water activities and that food can be a potential source of PMMoV in human feces through ingestion.

\section{ENVIRONMENTAL OCCURRENCE AND PERSISTENCE}

Modern molecular biological tools, most notably viral metagenomics using high-throughput next-generation sequencing technologies, have accelerated identification of novel microbial water quality indicators. The high prevalence of PMMoV in treated

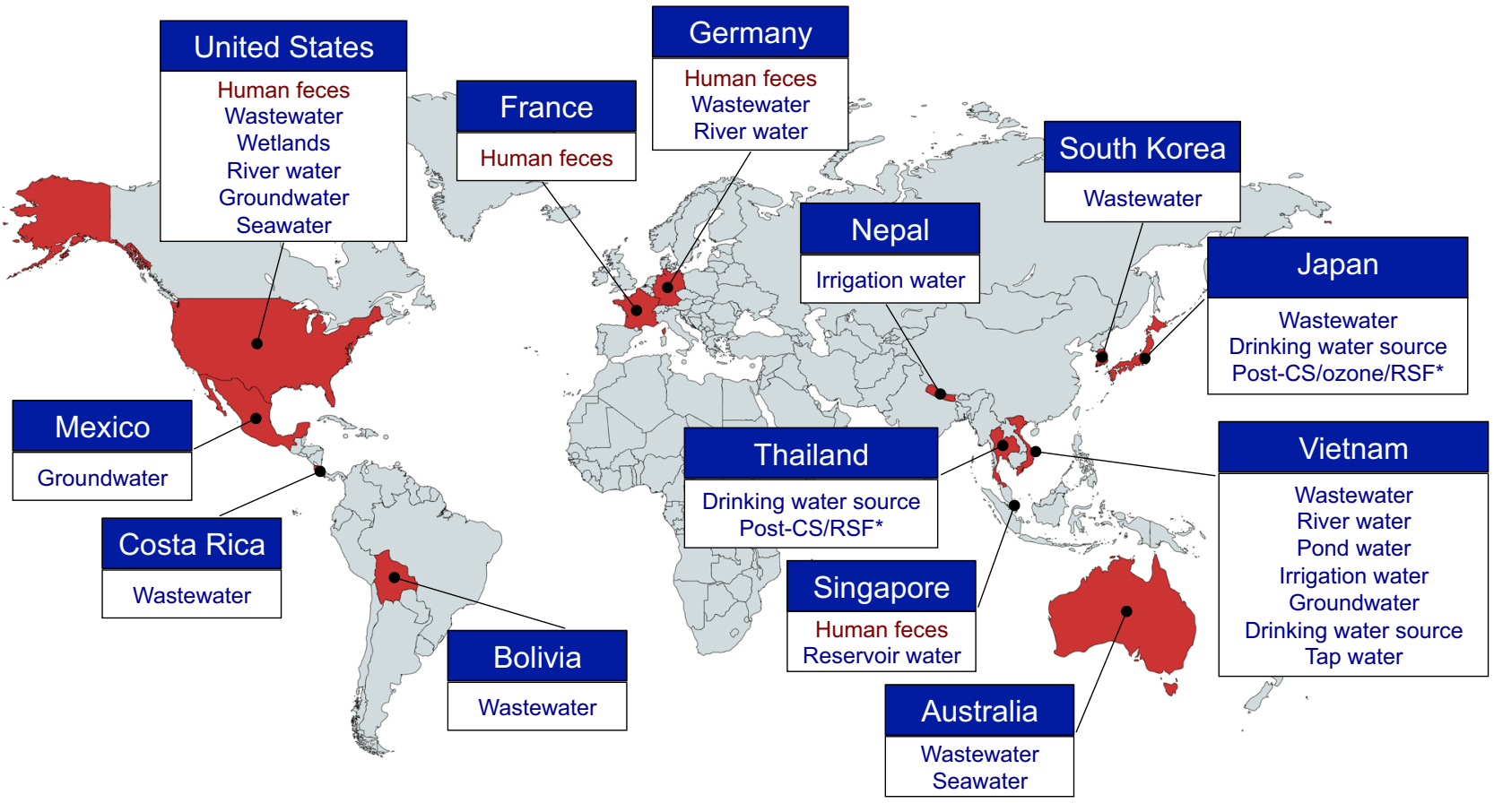

$\left({ }^{*} \mathrm{CS}\right.$, coagulation-sedimentation; RSF, rapid sand filtration)

Fig. 1 Countries and sample types of reported PMMoV detection in human feces and aquatic environments. The map was created using the web service operated by mapchart.net (http://www.mapchart.net) 
wastewaters has led many researchers to look for this virus in environmental waters. In this section, we summarize currently available data on the occurrence and persistence of PMMoV in urban water ways, such as wastewater and reclamation systems, surface waters, marine waters, and drinking water treatment systems, based on a comprehensive literature review.

\section{Wastewater and reclamation systems}

Occurrence. Identification of PMMoV in environmental water samples was first reported in 2009. Rosario et al. reported high abundance of PMMoV in wastewater and reclaimed water (i.e., treated wastewater for reuse) investigated with $\mathrm{qPCR}$ and viral metagenomics, respectively. ${ }^{24,30}$ Since PMMoV was found to be widespread and abundant in wastewater and seawater impacted by wastewater, it was suggested that this virus could be utilized as an indicator of human fecal pollution, especially in marine environments. ${ }^{24}$ Detection of PMMoV in wastewater using qPCR was subsequently reported from all over the world, including Germany, Vietnam, Costa Rica, Australia (Fig. 1). ${ }^{2,31-35}$ These studies reported that PMMoV was detected in almost all untreated wastewater samples with concentrations greater than $10^{5}$ genome copies (GC)/L (Table 2). One recent study carried out in Costa Rica documented that the specificity of PMMoV qPCR signal was $100 \%$ for domestic wastewater, as compared to $94 \%$ specificity of a human-specific (HF183) Bacteroides marker. ${ }^{34}$ In addition, Stachler et al. reported that $0.02 \% \pm 0.06 \%$ of metagenomic sequence reads originating from sewage and biosolids samples from the United States and Spain were mapped to PMMoV, which served as further metagenomic evidence for the higher abundance of $\mathrm{PMMoV}$ in wastewater compared to that of human pathogenic viruses (average number of mapped sequence reads: $395 \pm 619$ for PMMoV versus $102 \pm 66$ for norovirus [NoV]). ${ }^{36}$ These findings support the usefulness of PMMoV as a sensitive viral marker specific to domestic wastewater. A study conducted in South Korea reported that PMMoV was detected in untreated wastewater samples by regular RT-PCR with lower positive rate of $57.1 \%$, which may have been due to a difference in the sensitivity of the detection methods. ${ }^{37}$ PMMoV was also detected in most treated wastewater samples with concentrations greater than $10^{4}$ copies/L (Table 2). ${ }^{24,28,31-35,38}$

The prevalence of PMMoV in wastewater showed little seasonal variations. $^{11,31,33}$ PMMoV showed a higher concentration in wastewater than human enteric viruses. ${ }^{2,31-35,39}$ For example, Symonds et al. reported that the median and maximum PMMoV concentrations in untreated wastewater were at least an order of magnitude greater than those of human adenovirus (HAdV), human polyomavirus (HPyV), and NoV. ${ }^{34}$ This is most likely because PMMoV in human feces is of dietary origin (from peppers and their processed products such as hot sauce and curry), and its presence in feces is not dependent on active infection in humans; therefore it is excreted from large healthy human populations.

Removal and persistence. Reported values of reduction efficiency of PMMoV at wastewater treatment plants are summarized in Table 3. Reduction efficiencies of PMMoV by wastewater treatment were first reported in 2011 by Hamza et al. ${ }^{28}$ This study reported 1.7-3.7 $\log _{10}(n=12)$ reductions of PMMoV at a wastewater treatment plant in Germany that utilized a conventional activated sludge process. ${ }^{28}$ Subsequently, Kitajima et al. reported that reduction efficiencies of PMMoV by activated sludge and trickling filter were $0.76 \pm 0.53 \log _{10}(n=12)$ and $0.99 \pm 0.64$ $\log _{10}(n=12)$, respectively. ${ }^{31}$ PMMoV showed greater resistance to removal by conventional and advanced treatment systems, including Bardenpho, than any human enteric viruses. ${ }^{31,33}$ Symonds et al. investigated virus removal by two wastewater treatment pond systems (three-pond system and upflow anaerobic sludge blanket [UASB]-pond system) in Bolivia and reported

\begin{tabular}{|c|c|c|c|c|}
\hline Sample & $\begin{array}{l}\text { Samples } \\
\text { positive }\end{array}$ & $\begin{array}{l}\text { Concentration (genome } \\
\text { copies/L) for positive } \\
\text { samples }\end{array}$ & Country & \\
\hline \multicolumn{5}{|c|}{$\begin{array}{l}\text { Reference } \\
\text { Wastewater and reclamation systems }\end{array}$} \\
\hline \multirow[t]{9}{*}{ Raw wastewater } & $12 / 12$ & $1.5 \times 10^{8}-2.16 \times 10^{10}$ & US & ${ }^{24}$ \\
\hline & $24 / 24$ & $3.62 \times 10^{5}-1.36 \times 10^{7}$ & US & 31 \\
\hline & $12 / 12$ & $1.9 \times 10^{8}-9.6 \times 10^{8}$ & Germany & 28 \\
\hline & $2 / 2$ & $5.5 \times 10^{6}-7.2 \times 10^{6}$ & Vietnam & 32 \\
\hline & $24 / 24$ & $4.3 \times 10^{5}-1.32 \times 10^{9}$ & US & 33 \\
\hline & $8 / 8$ & Approx. $10^{5}-10^{8}$ & Costa Rica & 34 \\
\hline & & mean $5.72 \times 10^{7}$ & Australia & 35 \\
\hline & $8 / 14$ & NA & South Korea & 37 \\
\hline & $4 / 4$ & Approx. $10^{8}$ & Bolivia & 39 \\
\hline \multirow[t]{9}{*}{ Treated wastewater } & $12 / 12$ & $1.10 \times 10^{7}-7.00 \times 10^{9}$ & US & ${ }^{24}$ \\
\hline & $24 / 24$ & $1.18 \times 10^{5}-5.62 \times 10^{6}$ & US & 31 \\
\hline & $4 / 5$ & $5.84 \times 10^{5}-8.99 \times 10^{6}$ & US & 38 \\
\hline & $2 / 2$ & $6.5 \times 10^{5}-8.5 \times 10^{5}$ & Vietnam & 32 \\
\hline & $23 / 24$ & $1.26 \times 10^{4}-9.46 \times 10^{7}$ & US & 33 \\
\hline & & Mean $4.11 \times 10^{6}$ & Australia & 35 \\
\hline & $15 / 16$ & BQL-10 $0^{6.95}$ & US & 45 \\
\hline & $7 / 7$ & $10^{7.3}$ & Japan & 55 \\
\hline & $4 / 4$ & Approx. $10^{8.5}$ & Bolivia & 39 \\
\hline Constructed wetlands & $30 / 30$ & $1.73 \times 10^{4}-8.54 \times 10^{6}$ & US & 40 \\
\hline \multicolumn{5}{|l|}{ Freshwater environments } \\
\hline \multirow[t]{4}{*}{ River or reservoir water } & $108 / 108$ & $3.0 \times 10^{3}-1.1 \times 10^{6}$ & Germany & 28 \\
\hline & $3 / 3$ & $3.0 \times 10^{4}-1.8 \times 10^{6}$ & Vietnam & 32 \\
\hline & $47 / 48$ & BQL-10 $0^{5.59}$ & US & 45 \\
\hline & $118 / 171$ & mean $7.63 \times 10^{3}$ & Singapore & 56 \\
\hline Pond water & $10 / 11$ & 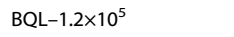 & Vietnam & 32 \\
\hline \multirow[t]{2}{*}{ Irrigation water } & $3 / 3$ & BQL-1.0× $10^{4}$ & Vietnam & 32 \\
\hline & $37 / 41$ & $\operatorname{Max} 5.01 \times 10^{8}$ & Nepal & 42 \\
\hline \multirow[t]{3}{*}{ Groundwater } & $3 / 8$ & BQL-9 & Vietnam & 32 \\
\hline & $17 / 20$ & Mean $2.03 \times 10^{3}$ & Mexico & 41 \\
\hline & $12 / 18$ & $\operatorname{Max} 1.44 \times 10^{6}$ & us & 38 \\
\hline \multicolumn{5}{|l|}{ Marine environment } \\
\hline \multirow[t]{3}{*}{ Seawater } & $4 / 6$ & Mean $2.85 \times 10^{6}$ & US & 24 \\
\hline & $4 / 12$ & $3.6 \times 10^{4}-8.6 \times 10^{4}$ & Australia & 35 \\
\hline & $18 / 30$ & $\operatorname{Max} 8.73 \times 10^{5}$ & US & 2 \\
\hline \multicolumn{5}{|l|}{ Drinking water systems } \\
\hline \multirow[t]{3}{*}{ Source water (river) } & $140 / 184$ & $2.03 \times 10^{3}-2.77 \times 10^{4}$ & Japan & 26 \\
\hline & $13 / 13$ & $10^{5.35 \pm 0.48}$ & Japan & 25 \\
\hline & $11 / 11$ & $10^{5.33 \pm 0.34}$ & Japan & 25 \\
\hline (pond) & $2 / 2$ & $1.9 \times 10^{5}-2.7 \times 10^{6}$ & Vietnam & 46 \\
\hline (groundwater) & $0 / 1$ & $\mathrm{BQL}$ & Vietnam & 46 \\
\hline (canal) & $\begin{array}{l}11 / 11 \\
(100 \%)\end{array}$ & $10^{2.88 \pm 0.35}$ & Thailand & 43 \\
\hline \multirow[t]{3}{*}{ Treated water (Post-CS) } & $9 / 11(82 \%)$ & $10^{2.39 \pm 0.55}$ & Thailand & 43 \\
\hline & $13 / 13$ & $10^{2.97 \pm 0.65}$ & Japan & 25 \\
\hline & $10 / 11$ & $10^{2.71 \pm 0.63}$ & Japan & 25 \\
\hline \multirow[t]{2}{*}{ (Post-CS-RSF) } & $\begin{array}{l}10 / 10 \\
(100 \%)\end{array}$ & $10^{1.06 \pm 0.53}$ & Thailand & 43 \\
\hline & $11 / 11$ & $10^{2.32 \pm 0.84}$ & Japan & 25 \\
\hline (Post-CS-ozone) & $5 / 13$ & $10^{0.91 \pm 0.84}$ & Japan & 25 \\
\hline (Post-CS-ozone-BAC) & $7 / 13$ & $10^{0.99 \pm 0.75}$ & Japan & 25 \\
\hline (Post-CS-ozone-BAC-RSF) & $4 / 13$ & $10^{1.23 \pm 0.42}$ & Japan & 25 \\
\hline \multirow[t]{2}{*}{ Tap water } & $0 / 6$ & $\mathrm{BQL}$ & Vietnam & 32 \\
\hline & $2 / 4$ & 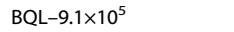 & Vietnam & 46 \\
\hline
\end{tabular}

NA not available (PMMoV-RNA was examined by regular RT-PCR), BQL below quantification or detection limit, CS coagulation-sedimentation, RSF rapid sand filtration, $B A C$ biological activated carbon

that no measureable reduction of PMMoV and enteric viruses (NoV genogroup I [GI] and rotavirus) was observed for either system. ${ }^{39}$ Rachmadi et al. investigated the attenuation of PMMoV by two surface flow wetlands in Arizona, United States, for additional wastewater treatment and reported that PMMoV exhibited little or no removal $(\leq 1 \mathrm{log}) .^{40}$ They also studied the persistence of PMMoV qPCR signal in wetland water based on controlled laboratory 
Table 3. Reduction of PMMoV at wastewater treatment plants

\begin{tabular}{|c|c|c|c|c|}
\hline Process & Country & $\log _{10}$ reduction & $n$ & Reference \\
\hline Activated sludge & Germany & $1.7-3.7$ & 12 & 28 \\
\hline Activated sludge & US & $0.76 \pm 0.53$ & 12 & 31 \\
\hline Trickling filter & US & $0.99 \pm 0.64$ & 12 & 31 \\
\hline $\begin{array}{l}\text { Sequential batch } \\
\text { reactor (SBR) }\end{array}$ & Vietnam & 0.92 & 2 & 32 \\
\hline Bardenpho & US & $0.9 \pm 0.5$ & 12 & 33 \\
\hline Bardenpho & US & $>2.7 \pm 1.6$ & 12 & 33 \\
\hline Three-pond system & Bolivia & $\begin{array}{l}\text { No measurable } \\
\text { reduction }\end{array}$ & 2 & 39 \\
\hline UASB-pond system & Bolivia & $\begin{array}{l}\text { No measurable } \\
\text { reduction }\end{array}$ & 2 & 39 \\
\hline
\end{tabular}

UASB upflow anaerobic sludge blanket

experiments and reported that PMMoV was not significantly reduced under a range of temperatures $\left(4-37^{\circ} \mathrm{C}\right)$ for 21 days. ${ }^{40}$ All of these studies suggest that PMMoV is more persistent than human enteric viruses in wastewater reclamation systems. These observations are consistent with a study based on laboratory-scale experiments, which reported that PMMoV showed greater stability in river water than enteric viruses like $\mathrm{HAdV}^{28}$ This may be because the capsid structure of PMMoV is more robust than that of human enteric viruses.

Although the behavior of PMMoV in the environment is not necessarily similar to that of enteric viruses because of differences in morphology between PMMoV (extremely stable rod-shaped virion with a length of more than $300 \mathrm{~nm}$ ) and enteric viruses (round-structured virion with a diameter of $30-90 \mathrm{~nm}$ ), PMMoV appears to be useful as a conservative "viral tracer" in wastewater reclamation systems.

\section{Freshwater environments}

Occurrence. PMMoV has been detected in aquatic environments around the world, including rivers, ${ }^{28,32}$ aquifers, ${ }^{41}$ irrigation, ${ }^{32,42}$ and coastal and marine waters (Fig. 1, Table 2). 2,24,43 Varying circumstances surrounding PMMoV presence in these water types have also been evaluated, such as rainy versus dry seasons, effluent influence, and correlation with other water pollution and quality indicators. ${ }^{2,24,32,41}$

PMMoV has been detected in rivers in at least three countries (Fig. 1, Table 2). Related viruses belonging to tobamoviruses were detected in river waters as early as 1989 , in Germany. ${ }^{44}$ In Germany, the Ruhr and Rhine rivers were sampled and analyzed for multiple viruses, including PMMoV, torque teno virus, HAdVs, human picobirnaviruses, and HPyVs. PMMoV was found in $100 \%$ ( $n=108)$ of samples analyzed. It was the only virus that was consistently detected throughout all samples. Concentrations for these samples ranged from $3.0 \times 10^{3}$ to $1.1 \times 10^{6} \mathrm{GC} / \mathrm{L}$. ${ }^{28}$ This range is similar to that of river water samples from Vietnam $(n=$ $3)$, where Kuroda et al. $^{32}$ reported a range of $3.0 \times 10^{4}-1.8 \times 10^{6}$ $\mathrm{GC} / \mathrm{L}$. The samples in this study were taken at varying points in river systems: upstream from an urban area, $500 \mathrm{~m}$ downstream of a wastewater treatment plant, and from a point that receives wastewater from a different area. ${ }^{32}$ This study also evaluated the presence of $\mathrm{PMMoV}$ in pond and irrigation waters. In pond waters, PMMoV was detected in 10/11 (91\%) samples, with concentrations ranging from non-quantifiable to $1.2 \times 10^{5} \mathrm{GC} / \mathrm{L}$. In irrigation waters, $3 / 3$ (100\%) samples were positive for PMMoV; however, only one sample had a quantifiable concentration of $1.0 \times 10^{4} \mathrm{GC}$ / L. ${ }^{32}$ Another study in 2017 looked at irrigation waters from the Kathmandu Valley from a variety of sources used for irrigating fresh produce. ${ }^{42}$ Thirty-five surface water and six groundwater samples were collected. Sampling sites included six rivers, two ponds, one canal, and six groundwater wells. PMMoV was detected in $96 \%$ of river samples $(27 / 28) ; 100 \%$ of canal samples $(2 / 2) ; 60 \%$ of pond samples $(3 / 5)$; and $83 \%$ of groundwater samples $(5 / 6){ }^{42}$

Betancourt et al. reported that PMMoV was more commonly detected than human enteric viruses (HAdV, enterovirus, and Aichi virus 1) in groundwater samples collected from managed aquifer recharge sites in Colorado, California, and Arizona in the United States. $^{38}$ In Mexico, groundwater samples showed fluctuating presence of PMMoV between the rainy and dry seasons. ${ }^{41}$ qPCR concentrations for PMMoV in freshwater during the "rainy season" samples ranged from $1.79 \times 10^{1}$ to $1.04 \times 10^{4} \mathrm{GC} / \mathrm{L}$. The corresponding $E$. coli counts were $<1 \mathrm{MPN} / 100 \mathrm{~mL}$ in $7 / 8$ (87.5\%) samples, with the remaining sample yielding a count of $8 \mathrm{MPN} /$ $100 \mathrm{~mL}$. During the "dry season", PMMoV concentrations ranged from $5.91 \times 10^{1}$ to $4.67 \times 10^{3} \mathrm{GC} / \mathrm{L}$. Again, E. coli MPN did not reflect these concentrations; in 6/8 (75\%) samples, <1 MPN/ $100 \mathrm{~mL}$ was reported. In brackish waters, PMMoV was only quantifiable in the "rainy season", with qPCR concentrations of $5.35 \times 10^{3}$ and $4.05 \times 10^{1} \mathrm{GC} / \mathrm{L}$; in the same samples, E. coli was undetectable. This study showed there was no correlation between PMMoV concentrations and E. coli or coliform concentrations, or physicochemical water parameters. ${ }^{41}$ Another study in which groundwaters were sampled from Vietnam showed only 3/ 8 (37.5\%) positives for PMMoV. Two of the samples were not quantifiable, while the third had a concentration of only $19 \mathrm{GC} / \mathrm{L}{ }^{32}$ It is likely that the presence of PMMoV in groundwater depends greatly on soil and aquifer conditions for a given area, thus leading to the variability in occurrence/concentrations between regions.

Persistence. PMMoV persistence in rivers downstream from treated effluent discharge was evaluated in Arizona and Colorado. $^{45}$ In this study, water was sampled at the effluent outfall and downstream. In Colorado, all samples $(n=6)$ collected were positive for PMMoV. In the South Platte River $(24 \mathrm{~km}$ downstream of the effluent outfall), the geometric mean concentration of PMMoV was $1.51 \times 10^{5} \mathrm{GC} / \mathrm{L}(n=3)$. These samples only showed a slight reduction from those collected at the outfall of the Denver Metro Wastewater Treatment Plant (mean $2.61 \times 10^{6} \mathrm{GC} / \mathrm{L}, n=3$ ). In Arizona, two stretches of the Santa Cruz River were sampled. For the Lower Santa Cruz River, which is primarily fed by effluent from the Ina Road Wastewater Treatment Plant, 2/3 (67\%) samples were positive for PMMoV; the virus was also detected in $2 / 3(67 \%)$ effluent samples as well. Again, there was little observed reduction between the geometric means for outfall and downstream. The concentrations for the outfall and downstream sites were $6.14 \times$ $10^{4}$ and $1.77 \times 10^{4} \mathrm{GC} / \mathrm{L}$, respectively. ${ }^{45}$ The Upper Santa Cruz River (USCR), which was sampled in the same study, is supplied by effluent from the Nogales International Water Treatment Center (NIWTC); more extensive sampling for this portion of the river was conducted. PMMoV was detected in 20/20 (100\%) samples from the NIWTC and downstream USCR. The mean concentrations for these sites were $7.28 \times 10^{5} \mathrm{GC} / \mathrm{L}$ at the outfall point and $8.20 \times 10^{4}$ $\mathrm{GC} / \mathrm{L}$ at the downstream sampling location; again, there was little reduction seen between these points. These results demonstrated the prolonged downstream detection of PMMoV in effluent-fed rivers, with less reduction compared to the human enteric viruses studied (HAdV, enterovirus, and Aichi virus 1).

Persistence has also been measured by qPCR under controlled laboratory conditions in a study that evaluated the stability of PMMoV in spiked river water samples over time at two different temperatures $\left(4^{\circ} \mathrm{C}\right.$ and $\left.25^{\circ} \mathrm{C}\right) .{ }^{28}$ Torque teno virus, HAdV, and HPyV were also evaluated along with PMMoV. Virus concentrations were determined at $1,3,6,10$, and 21 days after inoculation. Of the viruses tested, PMMoV appeared to be the most stable over time, showing no reduction until day 10 , and only a $1.1 \log _{10}$ reduction after 21 days at $25^{\circ} \mathrm{C}$, as compared to more substantial 
reductions for the other viruses: $3.0 \log _{10}$ (torque teno virus), 3.7 $\log _{10}(\mathrm{HAdV})$, and $4.2 \log _{10}(\mathrm{HPyV}) .^{28}$ All viruses were more stable at $4{ }^{\circ} \mathrm{C}$. At this temperature, PMMoV showed less than $0.5 \log _{10}$ reduction after 21 days of incubation in river water. This study confirms that PMMoV viral particles are very stable at a range of temperatures.

\section{Marine environment}

Occurrence. In marine waters from the Gulf Stream (USA), PMMoV was not detected when influence from wastewater effluent was absent. ${ }^{24}$ In sample locations that were positive (4/ $7)$, the concentrations of the virus ranged from $4.09 \times 10^{5}$ to $6.00 \times 10^{7} \mathrm{GC} / \mathrm{L}$. Detection of PMMoV coincided with the detection of other indicators and pathogenic organisms. ${ }^{24}$ Similarly, in coastal waters around Florida, PMMoV presence correlated to the presence of multiple microbial sourcetracking (MST) markers. ${ }^{2} \mathrm{~A}$ total of 30 samples, from five coastal regions were collected. Sites also included a combination of ocean wastewater outfalls, and inlet sites. Of these samples, PMMoV was detected in 60\% (18/30). Concentrations for these samples ranged from below level of quantification to $8.73 \times 10^{5} \mathrm{GC} / \mathrm{L}$ (Table 2). ${ }^{2}$ Coastal waters were also evaluated around Costa Rica, in the Gulf of Nicoya. ${ }^{34}$ In this study, eight samples were collected from four important locations for shellfish production in Costa Rica. In all coastal samples, PMMoV and other MST markers were not detected. However, low levels of FIB and $E$. coli were quantified, which suggests that there is little impact from wastewater discharge in these areas. This is one of the few published studies to be unable to detect PMMoV in any environmental water samples. ${ }^{34}$ Beach water samples taken from southeast Queensland, Australia, were tested for PMMoV as an MST organism for fecal pollution of coastal environments. ${ }^{35}$ Results from this study yielded only $33.3 \%$ (4/12) water samples positive for PMMoV. Concentrations recovered for these samples ranged from $3.6 \times 10^{4}$ to $8.6 \times 10^{4} \mathrm{GC} / \mathrm{L}$ (Table 2). ${ }^{35}$

Persistence. Rosario et al. evaluated the persistence of the PMMoV detectability in a controlled experiment using seawater. In this study, replicate seawater samples were collected in tubes and spiked with raw wastewater. The tubes were placed off of a seawall, and samples were collected at 1, 2, 3, 4, 5, 6, 7, 14, 21, and 28 days following. This allowed for a controlled, in situ experiment, with natural temperatures and environmental conditions. The seawater temperature was estimated to range from 31 to $33^{\circ} \mathrm{C}$ over the course of the study. ${ }^{24}$ Results from this incubation study showed that PMMoV was still detectable by qPCR after 7 days of incubation. From this, the authors deduced the half-life of PMMoV in seawater at temperatures between 31 and $33^{\circ} \mathrm{C}$ to be 1.54 days.

\section{Drinking water systems}

Occurrence. Haramoto et al. sampled drinking water sources in Japan from seven different geographical regions throughout the country. The sampled surface water sources supply 30 drinking water treatment plants (DWTPs) throughout these regions. ${ }^{26}$ PMMoV was detected in 140/184 total samples (76\%). Of these samples, ten drinking water sources tested positive for all samples taken; there were only three sources in which PMMoV was not detected for any sampling rounds. Concentration for PMMoV from qPCR ranged from $2.03 \times 10^{3}$ to $2.77 \times 10^{4} \mathrm{GC} / \mathrm{L}$ (Table 2). ${ }^{26}$ This study also evaluated potential seasonal variation in detection frequency and concentration among autumn, winter, and summer months; there were no significant differences among the seasons for detection or concentration of PMMoV. ${ }^{26}$ However, there was a significant difference among the seven regions sampled, with two urban, population-dense areas accounting for a large proportion of positives. This significant difference was attributed to higher levels of fecal pollution, and was confirmed by increased presence of E. coli. ${ }^{26}$ Nucleotide sequencing analysis of PMMoV was also performed for tested water samples and revealed that there were genetically diverse PMMoV strains, including those with an $L^{3}$ resistance-breaking gene that are more pathogenic to peppers, in drinking water sources in Japan.

Asami et al. determined the occurrence of PMMoV before and after treatment processes at a full-scale DWTP in Bangkok, Thailand. The concentrations of PMMoV in raw water (canal water), post coagulation-sedimentation (CS), and post rapid sand filtration (RSF) were determined to be $10^{2.88 \pm 0.35}, 10^{2.39 \pm 0.55}$, and $10^{1.06 \pm 0.53} \mathrm{GC} / \mathrm{L}$, respectively (Table 2). ${ }^{43} \mathrm{PMMoV}$ was detected more frequently than any other viruses tested in this study (i.e., NoVs, Aichi virus 1, enteric HAdV, enterovirus, HPyVs). Sangsanont et al. determined the occurrence of PMMoV in drinking water sources in Hanoi, Vietnam. ${ }^{46}$ The concentration of PMMoV varied from $1.9 \times 10^{5}$ to $2.7 \times 10^{6} \mathrm{GC} / \mathrm{L}$ and was detected even in tap water samples at a concentration of up to $9.1 \times 10^{5} \mathrm{GC} / \mathrm{L}$ (Table 2 ). The presence or absence of PMMoV did not correlate with $E$. coli or total coliforms. Kato et al. ${ }^{25}$ detected PMMoV at several stages of treatment in two full-scale DWTPs in Japan, even detecting the virus in some samples after advanced treatment with ozone (although at decreased concentrations). Concentrations of PMMoV in a plant (CS followed by ozonation, biological activated carbon $[B A C]$, chlorination, and RSF) for raw water, post-CS, postozonation, post-BAC, and post-RSF were $10^{5.35 \pm 0.48}, 10^{2.97 \pm 0.65}$, $10^{0.91 \pm 0.84}, 10^{0.99 \pm 0.75}$, and $10^{1.23 \pm 0.42} \mathrm{GC} / \mathrm{L}$, respectively. Concen-' trations for the other plant (CS followed by RSF and subsequent treatment processes) were determined for raw water, post-CS, and post-RSF to be $10^{5.33 \pm 0.34}, 10^{2.71 \pm 0.63}$, and $10^{2.32 \pm 0.84} \mathrm{GC} / \mathrm{L}$, respectively (Table 2 ).

Removal and persistence. Several studies have evaluated the removal of PMMoV by drinking water treatment processes, utilizing both bench-scale experiments and full-scale plant monitoring. Shirasaki et al. investigated the removal of PMMoV by membrane filtration (MF) with and without coagulation as well as ultrafiltration (UF) and compared it to that of other enteric viruses (HAdV type 40, coxsackievirus B5, and hepatitis A virus IB), $M N V$, and fecal indicators at bench-scale, including two coliphages (MS2 and $\phi X 174)$. Removal of PMMoV for all filtration processes was highly correlated with the enteric viruses tested as well as MNV, with comparable $\log _{10}$ reductions. Notably, PMMoV was removed in a similar fashion to the enteric viruses when membranes of decreasing pore size were investigated, indicating that size and shape differences between the viruses appeared not to impact virus removal trends. Similar removal of PMMoV during coagulation experiments also indicates that PMMoV is removed in a similar fashion to other enteric viruses during coagulation. Kato et al. ${ }^{25}$ investigated removal of PMMoV at benchscale by coagulation-sedimentation (CS) with polyaluminum chloride (PACl) followed by RSF and compared reductions to that of NoV GIl, MNV, and several fecal indicators (Q $\beta, M S 2$, Aichi virus 1, and $E$. coli). PMMoV was found to be removed by CS $\left(1.96 \pm 0.30 \log _{10}\right)$ more than by RSF $\left(0.26 \pm 0.38 \log _{10}\right)$; in general, $\log _{10}$ reductions of PMMoV were more comparable to that of other viruses (Aichi virus 1, MNV, NoV GII, Q $\beta$, and MS2) than E. coli or turbidity reductions. For example, removal by these processes was not significantly different $(p>0.05)$ from that of NoV GII $(1.86 \pm 0.61$ and $0.28 \pm 0.46 \log _{10}$, respectively); a positive correlation was observed between NoV GII and PMMoV removal, indicating that PMMoV may be a suitable indicator of NoV Gll removal in full-scale plants.

In addition to benchscale experiments, the abundance of PMMoV in drinking water sources has led to its use as a virus removal efficiency indicator in full-scale DWTPs. Asami et al. calculated step-wise virus removal efficiencies at a DWTP in Bangkok, Thailand, based on the concentrations of indigenous PMMoV before and after each treatment process (i.e., CS w/ aluminum sulfate, and RSF). ${ }^{43}$ Some variation was observed 
between wet and dry seasons; during the wet season, PMMoV was removed less by CS and more by RSF on average $\left(0.40 \log _{10}\right.$ and $1.26 \log _{10}$, respectively), whereas during the dry season CS removed most PMMoV (1.61 $\log _{10}$ by CS and $0.78 \log _{10}$ by RSF). The difference between seasons was potentially due to variations in raw water quality and the characteristics of PMMoV itself. PMMoV removal was similar to that of JCPyV during the dry season only. However, during the wet season, reductions by CS were notably lower for PMMoV in comparison; this could be due to inherent differences in virus coagulation resulting from capsid structure and surface charge in this particular matrix.

Kato et al. ${ }^{25}$ evaluated step-wise removal of PMMoV in sampling campaigns at two full-scale DWTPs in Japan, with one sample set monitoring reductions through a complete treatment train utilizing advanced ozone treatment. Reductions of PMMoV by CS (plant A: $\sim 2.38 \log _{10}$; plant B $2.62 \log _{10}$ ), were notably higher than reductions of turbidity and indicator bacteria. These PMMoV reductions were notably greater than those observed by Asami et al. in Thailand for CS; this difference is attributable to the pre-chlorination of raw waters and use of a more efficient coagulant $(\mathrm{PACl})$ in Japanese plants in the study by Kato et al. ${ }^{25}$ Ozone treatment resulted in significant reductions $\left(\sim 2 \log _{10}\right)$ of PMMoV at plant $A$, although PMMoV genomes could still be detected post-ozonation. Reductions by BAC in plant $A$ and RSF in both plants were found to be negligible; of particular note, reductions of PMMoV by RSF were less than those observed for $E$. coli and turbidity. Although turbidity and indicator bacteria were removed by the processes in both plants, their removal did not necessarily align with PMMoV removal rates observed, indicating that the processes leading to PMMoV removal are not necessarily reflected by the other two parameters.

These studies taken together indicate that PMMoV, despite differences in size, shape, and surface charge properties compared to enteric viruses, represents a good target for measuring virus reduction efficiencies comparable to that of enteric viruses for drinking water treatment processes, especially when compared to reductions of indicator bacteria or turbidity which may not represent virus reductions. The abundance and high concentration of PMMoV in fecally impacted waters also lends to its utility as a readily detectable indicator in cases where the concentrations of target enteric viruses are comparably low.

\section{SUITABILITY OF PMMOV AS A VIRAL INDICATOR OF HUMAN FECAL POLLUTION}

Table 4 summarizes the criteria for an ideal indicator organism and the features of PMMoV for each criterion to evaluate the suitability of PMMoV as a viral indicator of human fecal pollution in aquatic environments. It appears that PMMoV has various advantages as well as limitations, which are discussed in this section.

\section{Advantages}

High abundance and persistence. The most remarkable advantage of PMMoV as an indicator organism is that it can be more consistently observed in quantifiable and higher concentrations than any human virus without substantial seasonal fluctuations in environmental occurrence. ${ }^{26,31,33}$ In other words, PMMoV can be present whenever human enteric viruses are present, and PMMoV qPCR signals serve as a sensitive biological marker indicating the presence of viral pathogens in a given environmental water sample. This is generally applicable to all types of water, including wastewater, river water, groundwater, marine water, and drinking water.

It has also been demonstrated by controlled laboratory experiments that PMMoV shows greater stability than other human enteric viruses in environmental water, specifically river water, ${ }^{28}$ marine water, ${ }^{24}$ and wetland water. ${ }^{40}$ This unique feature of PMMoV in terms of environmental stability supports its usefulness as a performance indicator in water and wastewater treatment plants to evaluate treatment efficiency, as suggested for wastewater reclamation systems ${ }^{31}$ and coagulation-RSF. ${ }^{47}$ The application of PMMoV as a performance indicator can be extended to other treatment processes, such as membrane filtration and disinfection, although more research is necessary in the case of the latter to determine if reductions of PMMoV by different disinfection methods are relatable to that of enteric viruses.

In comparison to chemical markers, PMMoV can be considered to have more advantages as a viral tracer of fecal pollution. This is partly because PMMoV should behave more similarly to enteric viruses than chemical markers. In fact, Symonds et al. reported that the proportion of particle-bound PMMoV particles to total PMMoV particles in wastewater treatment ponds was comparable to that of NoV Gl and human rotavirus. ${ }^{39}$ Kuroda et al. reported that the utility of PMMoV as a tracer for wastewater contamination in surface water was shown to be comparable to that of caffeine, which is a widely used chemical marker for human fecal contamination in water bodies. ${ }^{48}$ Specifically, the abundance of PMMoV in untreated wastewater, the dynamic range in concentration, the persistence and ubiquity in surface water were comparable to caffeine or greater. ${ }^{32}$

The potential use of PMMoV as an MST marker has been suggested due to its high abundance and stability in aquatic environments and lack of seasonal variations. In fact, PMMoV has been employed as a viral marker in MST studies investigating human fecal/sewage pollution in coastal waters $s^{2,34,35,49}$ and attracting much attention as a new MST tool. ${ }^{50}$ Further studies on the specificity of PMMoV are needed to confirm its suitability as an MST marker for human fecal pollution. ${ }^{50}$

Convenience in detection and laboratory testing. Despite the fact that detection of DNA viral indicators, such as HAdV or HPyV, is easier than RNA viruses (as it does not require an RT step), ${ }^{51,52}$ PMMoV can be easily tested together with other enteric viruses of

Table 4. Suitability of PMMoV as an indicator organism

\begin{tabular}{|c|c|c|}
\hline Criteria for an ideal indicator organism ${ }^{a}$ & Suitability of PMMoV & Representative references \\
\hline Present whenever enteric pathogens are present & Yes, higher occurrence than most enteric pathogens & This review \\
\hline No growth in water & No growth without its host plant & 13 \\
\hline Testing method is easy to perform & Yes, can be analyzed together with viral pathogens & 32 \\
\hline Be a member of the intestinal microflora of warm-blooded animals & Yes, abundant in human fecal virome & 11,29 \\
\hline
\end{tabular}


interest via molecular biological methods (e.g., RT-qPCR), because PMMoV possesses an RNA genome as with many human enteric viruses. This is especially beneficial for studies that are associated with assessment and management of viral water quality.

PMMoV has been deemed non-pathogenic for humans, which serves as another important advantage as an indicator. It is easier and safer to work with PMMoV than potentially pathogenic indicators in both environmental detection and laboratory-scale experiments.

\section{Limitations}

Morphological and surface charge differences compared to human viruses. The morphology of PMMoV (rod shaped) does not resemble that of human enteric viruses (icosohedral shaped) and the $\mathrm{pl}$ is notably different between them. ${ }^{13,19,20}$ This may lead to differences in environmental behavior and removal/reduction rates during treatment processes under certain circumstances, as well as recovery efficiencies for virus concentration methods. Further investigation is required to determine to what degree each of these factors contributes to significant differences in viral capture and removal behaviors between PMMoV and enteric viruses of interest.

Inconsistent occurrence and behavior with human viruses. Several reports have pointed out the limitation of PMMoV as a viral indicator because of inconsistent occurrence and behavior compared to human viruses. Kuroda et al. concluded that PMMoV is not suitable as a fecal indicator or tracer in groundwater, tap water, and bottled water, because the detection rates and concentration of PMMoV in those waters were very low and the occurrence did not agree with those of pharmaceuticals and personal care products and enteric viruses. ${ }^{32}$ Hamza et al. also argued that PMMoV may not be suitable for discerning fresh fecal pollution in water bodies, which is likely to be associated with pathogens, because of its extremely high environmental stability. ${ }^{28}$ In addition, a study conducted in Bolivia reported that PMMoV was not detected in any surface water samples, despite the detection of FIB. ${ }^{2}$

\section{CONCLUSIONS}

We have evaluated the suitability of PMMoV as a viral indicator for human fecal pollution in various settings in urban water systems based on a detailed review of the currently available literature. The results of this review have revealed that PMMoV is globally distributed and present in various water sources in greater abundance than human pathogenic viruses, without substantial seasonal fluctuations. In addition, increased concentrations of PMMoV tend to be correlated with increased fecal contamination in general, along with more frequent detection of pathogenic enteric viruses. Although PMMoV offers attractive features as an indicator for fecal contamination, this review has also identified research gaps in utilizing $\mathrm{PMMoV}$ as a microbial water quality indicator to protect public health. PMMoV exhibits remarkable stability in water under various environmental conditions (physicochemical and biological), and this may lead to overly conservative estimates in viral persistence and infection risks; however, it is because of this persistence that PMMoV can be detected throughout treatment plant processes and thus PMMoV holds particular value as a virus reduction efficiency indicator in these systems. PMMoV exhibits unique features as a viral indicator, but its behavior in aquatic environments and relation to viruses causing public health risks should be investigated more in-depth to obtain a better understanding of its usefulness as a representation of potential human fecal pollution as well as pathogen contamination and removal. A framework for integrating PMMoV into quantitative microbial risk assessment and even water quality regulations should be established based on a proper interpretation of PMMoV occurrence/persistence data. By addressing these research gaps, it should be possible to utilize this virus more wisely and properly as a microbial tool for improved microbial water quality management.

\section{ACKNOWLEDGEMENTS}

This work was partly supported by the Japan Society for the Promotion of Science (JSPS) through Grant-in-Aid for Scientific Research (B) (17H03332).

\section{AUTHOR CONTRIBUTIONS}

M.K., H.P.S., and J.R.T. designed the work, compiled the data, and wrote the paper.

\section{ADDITIONAL INFORMATION}

Competing interests: The authors declare no competing interests.

Publisher's note: Springer Nature remains neutral with regard to jurisdictional claims in published maps and institutional affiliations.

\section{REFERENCES}

1. Harwood, V. J., Staley, C., Badgley, B. D., Borges, K. \& Korajkic, A. Microbial source tracking markers for detection of fecal contamination in environmental waters: relationships between pathogens and human health outcomes. FEMS Microbiol. Rev. 38, 1-40 (2014)

2. Symonds, E. M. et al. Faecal pollution along the southeastern coast of Florida and insight into the use of pepper mild mottle virus as an indicator. J. Appl. Microbiol. 121, 1469-1481 (2016).

3. Sinclair, R. G., Jones, E. L. \& Gerba, C. P. Viruses in recreational water-borne disease outbreaks: a review. J. Appl. Microbiol. 107, 1769-1780 (2009).

4. U.S. Environmental Protection Agency (USEPA). Review of coliphages as possible indicators of fecal contamination for ambient water quality (820-R-15-098). (2015).

5. Ashbolt, N., Grabow, W. \& Snozzi, M. Indicators of microbial water quality. Water Qual. Guidel. Stand. Health 289-316 (2001).

6. U.S. Environmental Protection Agency (USEPA). Voluntary Estuary Monitoring Manual (2006).

7. U.S. Environmental Protection Agency (USEPA). Human health recreational ambient water quality criteria or swimming advisories for Microcystins and Cylindrospermopsin-Draft. (2016).

8. Harwood, V. J. et al. Validity of the indicator organism paradigm for pathogen reduction in reclaimed water and public health protection. Appl. Environ. Microbiol. 71, 3163-3170 (2005).

9. Liang, L. et al. Alternative fecal indicators and their empirical relationships with enteric viruses, Salmonella enterica, and Pseudomonas aeruginosa in surface waters of a tropical urban catchment. Appl. Environ. Microbiol. 81, 850-860 (2015).

10. Gerba, C. P., Goyal, S. M., Labelle, R. L., Cech, I. \& Bogdan, G. F. Failure of indicator bacteria to reflect the occurrence of enteroviruses in marine waters. Am. J. Public Health 69, 1116-1119 (1979).

11. Zhang, T. et al. RNA viral community in human feces: prevalence of plant pathogenic viruses. PLoS Biol. 4, 0108-0118 (2006).

12. King, A. M. Q. et al. (eds) Virus Taxonomy: Ninth Report of the International Committee on Taxonomy of Viruses (Elsevier, Amsterdam, The Netherlands, 2011).

13. Wetter, C., Conti, M., Altschuh, D., Tabillion, R. \& van Regenmortel, M. H. V. Pepper mild mottle virus, a tobamovirus infecting pepper cultivars in Sicily. Phytopathology 74, 405-410 (1984).

14. Martínez-Ochoa, N., Langston, D. B., Mullis, S. W. \& Flanders, J. T. First report of Pepper mild mottle virus in jalapeno pepper in Georgia. Plant Health Prog. 42, 34-37 (2003).

15. Hagiwara, K., Ichiki, T. U., Ogawa, Y., Omura, T. \& Tsuda, S. A single amino acid substitution in 126-kDa protein of Pepper mild mottle virus associates with symptom attenuation in pepper; the complete nucleotide sequence of an attenuated strain, C-1421. Arch. Virol. 147, 833-840 (2002).

16. Wang, X., Liu, F., Zhou, G., Li, X.-H. \& Li, Z. Detection and molecular characterization of Pepper mild mottle virus in China. J. Phytopathol. 154, 755-757 (2006).

17. Jarret, R. L., Gillaspie, A. G., Barkely, N. A. \& Pinnow, D. L. The occurrence and control of pepper mild mottle virus (PMMoV) in the USDA/ARS Capsicum germplasm collection. Seed Technol. 30, 26-36 (2008).

18. Alonso, E. et al. Nucleotide sequence of the genomic RNA of pepper mild mottle virus, a resistance-breaking tobamovirus in pepper. J. Gen. Virol. 72, 2875-2884 (1991). 
19. Shirasaki, N., Matsushita, T., Matsui, Y. \& Murai, K. Assessment of the efficacy of membrane filtration processes to remove human enteric viruses and the suitability of bacteriophages and a plant virus as surrogates for those viruses. Water Res. 115, 29-39 (2017).

20. Michen, B. \& Graule, T. Isoelectric points of viruses. J. Appl. Microbiol. 109, 388-397 (2010)

21. Roberts, P.D. \& Adkins, S. Pepper mild mottle virus. Univ. Florida IFAS Ext. Bull. HS808 (2001).

22. Rialch, N., Sharma, V., Sharma, A. \& Sharma, P. N. Characterization and complete nucleotide sequencing of Pepper Mild Mottle Virus infecting bell pepper in India. Phytoparasitica 43, 327-337 (2015).

23. Aguilar, M. I., Guirado, M. L., Melero-Vara, J. M. \& Gómez, J. Efficacy of composting infected plant residues in reducing the viability of Pepper mild mottle virus, Melon necrotic spot virus and its vector, the soil-borne fungus Olpidium bornovanus. Crop. Prot. 29, 342-348 (2010).

24. Rosario, K., Symonds, E. M., Sinigalliano, C., Stewart, J. \& Breitbart, M. Pepper mild mottle virus as an indicator of fecal pollution. Appl. Environ. Microbiol. 75 7261-7267 (2009).

25. Kato, R., Asami, T., Utagawa, E., Furumai, H. \& Katayama, H. Pepper mild mottle virus as a process indicator at drinking water treatment plants employing coagulation-sedimentation, rapid sand filtration, ozonation, and biological activated carbon treatments in Japan. Water Res. 132, 61-70 (2018).

26. Haramoto, E. et al. Occurrence of pepper mild mottle virus in drinking wate sources in Japan. Appl. Environ. Microbiol. 79, 7413-7418 (2013).

27. Bolton, S. L. et al. Sanitizer efficacy against murine norovirus, a surrogate for human norovirus, on stainless steel surfaces when using three application methods. Appl. Environ. Microbiol. 79, 1368-1377 (2013).

28. Hamza, I. A., Jurzik, L., Überla, K. \& Wilhelm, M. Evaluation of pepper mild mottle virus, human picobirnavirus and Torque teno virus as indicators of fecal contamination in river water. Water Res. 45, 1358-1368 (2011).

29. Colson, P. et al. Pepper mild mottle virus, a plant virus associated with specific immune responses, fever, abdominal pains, and pruritus in humans. PLOS ONE 5 , e10041 (2010)

30. Rosario, K., Nilsson, C., Lim, Y. W., Ruan, Y. \& Breitbart, M. Metagenomic analysis of viruses in reclaimed water. Environ. Microbiol. 11, 2806-2820 (2009).

31. Kitajima, M., Iker, B. C., Pepper, I. L. \& Gerba, C. P. Relative abundance and treatment reduction of viruses during wastewater treatment processes - identification of potential viral indicators. Sci. Total Environ. 488-489, 290-296 (2014).

32. Kuroda, K. et al. Pepper mild mottle virus as an indicator and a tracer of fecal pollution in water environments: Comparative evaluation with wastewater-tracer pharmaceuticals in Hanoi, Vietnam. Sci. Total Environ. 506-507, 287-298 (2015).

33. Schmitz, B. W., Kitajima, M., Campillo, M. E., Gerba, C. P. \& Pepper, I. L. Virus reduction during advanced Bardenpho and conventional wastewater treatment processes. Environ. Sci. Technol. 50, 9524-9532 (2016).

34. Symonds, E. M. et al. Microbial source tracking in shell fish harvesting waters in the Gulf of Nicoya, Costa Rica. Water Res. 111, 177-184 (2017).

35. Hughes, B., Beale, D., Dennis, P., Cook, S. \& Ahmed, W. Cross-comparison of human wastewater-associated molecular markers in relation to fecal indicator bacteria and enteric viruses in recreational beach waters. Appl. Environ. Microbiol. 83, e00028-17 (2017).

36. Stachler, E. \& Bibby, K. Metagenomic evaluation of the highly abundant human gut bacteriophage crAssphage for source tracking of human fecal pollution. Environ. Sci. Technol. Lett. 1, 405-409 (2014).

37. Han, T. H., Kim, S. C., Kim, S. T., Chung, C. H. \& Chung, J. Y. Detection of norovirus genogroup IV, klassevirus, and pepper mild mottle virus in sewage samples in South Korea. Arch. Virol. 159, 457-463 (2014).

38. Betancourt, W. Q. et al. Assessment of virus removal by managed aquifer recharge at three full-scale operations. J. Environ. Sci. Health A Tox. Hazard. Subst. Environ. Eng. 49, 1685-1692 (2014).

39. Symonds, E. M. et al. A case study of enteric virus removal and insights into the associated risk of water reuse for two wastewater treatment pond systems in Bolivia. Water Res. 65, 257-270 (2014).

40. Rachmadi, A. T., Kitajima, M., Pepper, I. L. \& Gerba, C. P. Enteric and indicator virus removal by surface flow wetlands. Sci. Total Environ. 542, 976-982 (2016).

41. Rosiles-González, G. et al. Occurrence of pepper mild mottle virus (PMMoV) in groundwater from a karst aquifer system in the Yucatan Peninsula, Mexico. Food Environ. Virol. 9, 487-497 (2017).
42. Shrestha, S., Shrestha, S., Shindo, J., Sherchand, J. B. \& Haramoto, E. Virological quality of irrigation water sources and pepper mild mottle virus and tobacco mosaic virus as index of pathogenic virus contamination level. Food Environ. Virol. 10, 107-120 (2018)

43. Asami, T., Katayama, H., Torrey, J. R., Visvanathan, C. \& Furumai, H. Evaluation of virus removal efficiency of coagulation-sedimentation and rapid sand filtration processes in a drinking water treatment plant in Bangkok, Thailand. Water Res. 101, 84-94 (2016).

44. Buttner, C. \& Nienhaus, F. Virus contamination of waters in two forest districts of the Rhineland area (FRG). Eur. J. Plant Pathol. 19, 206-211 (1989).

45. Sassi, H. P., Tuttle, K. D., Betancourt, W. Q., Kitajima, M. \& Gerba, C. P. Persistence of viruses by $\mathrm{qPCR}$ in three effluent-dominated rivers in the western United States. Food Environ. Virol. 10, 297-304 (2018).

46. Sangsanont, J., Dan, D. T., Nga, T. T. V., Katayama, H. \& Furumai, H. Detection of pepper mild mottle virus as an indicator for drinking water quality in Hanoi, Vietnam, in large volume of water after household treatment. J. Environ. Sci. Health A Tox. Hazard. Subst. Environ. Eng. 51, 1100-1106 (2016).

47. Shirasaki, N., Matsushita, T., Matsui, Y. \& Yamashita, R. Evaluation of the suitability of a plant virus, pepper mild mottle virus, as a surrogate of human enteric viruses for assessment of the efficacy of coagulationerapid sand filtration to remove those viruses. Water Res. 129, 460-469 (2018).

48. Glassmeyer, S. T. et al. Transport of chemical and microbial compounds from known wastewater discharges: potential for use as indicators of human fecal contamination. Environ. Sci. Technol. 39, 5157-5169 (2005).

49. Ahmed, W. et al. Quantitative microbial risk assessment of microbial source tracking markers in recreational water contaminated with fresh untreated and secondary treated sewage. Environ. Int. 117, 243-249 (2018).

50. Wong, K., Fong, T. T., Bibby, K. \& Molina, M. Application of enteric viruses for fecal pollution source tracking in environmental waters. Environ. Int. 45, 151-164 (2012).

51. Rachmadi, A. T., Torrey, J. R. \& Kitajima, M. Human polyomavirus: advantages and limitations as a human-specific viral marker in aquatic environments. Water Res. 105, 456-469 (2016).

52. Rames, E., Roiko, A., Stratton, H. \& Macdonald, J. Technical aspects of using human adenovirus as a viral water quality indicator. Water Res. 96, 308-326 (2016)

53. Çağlar, B. K., Fidan, H. \& Elbeaino, T. Detection and molecular characterization of pepper mild mottle virus from Turkey. J. Phytopathol. 161, 434-438 (2013).

54. Chung, B. N. et al. Tomato spotted wilt virus isolates giving different infection in commercial Capsicum annuum cultivars. Plant Pathol. J. 28, 87-92 (2012).

55. Lee, S., Hata, A., Yamashita, N. \& Tanaka, H. Evaluation of virus reduction by ultrafiltration with coagulation-sedimentation in water reclamation. Food Environ. Virol. 9, 453-463 (2017).

56. Saeidi, N. et al. Occurrence of traditional and alternative fecal indicators in tropical urban environments under different land use patterns. Appl. Environ. Microbiol. 84, e00287-18 (2018).

57. Kitajima, M., Iker, B. C., Pepper, I. L. \& Gerba, C. P. Relative abundance and treatment reduction of viruses during wastewater treatment processes - Identification of potential viral indicators. Sci. Total Environ. 488-489, 290-296 (2014).

58. Gerba, C. P. in Environmental Microbiology 3rd edn (eds Pepper, I. L., Gerba, C. P. \& Gentry T. J.) Ch. 23 (Elsevier, Amsterdam, The Netherlands, 2015).

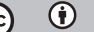

Open Access This article is licensed under a Creative Commons Attribution 4.0 International License, which permits use, sharing, adaptation, distribution and reproduction in any medium or format, as long as you give appropriate credit to the original author(s) and the source, provide a link to the Creative Commons license, and indicate if changes were made. The images or other third party material in this article are included in the article's Creative Commons license, unless indicated otherwise in a credit line to the material. If material is not included in the article's Creative Commons license and your intended use is not permitted by statutory regulation or exceeds the permitted use, you will need to obtain permission directly from the copyright holder. To view a copy of this license, visit http://creativecommons. org/licenses/by/4.0/.

(c) The Author(s) 2018 